\title{
Deconstructing the Sykes-Picot Myth: Frontiers, Boundaries, Borders and the Evolution of Ottoman Territoriality
}

\author{
Ali Murat Kurşun \\ Aberystwyth University
}

\begin{abstract}
This study aims to evaluate the emergence of the Sykes-Picot order and deconstruct its mythologization by proposing an evolutionary assessment of border understanding. This study addresses the following primary research questions: How did the interplay of domestic, regional, and international developments lay the groundwork for the formation of the Sykes-Picot territorial order? How was the administrative structure and regional divisions before the Sykes-Picot agreement and to which border categorizations did these structures correspond? Was the Sykes-Picot agreement the only international intervention that affected the borders of the region or were there other international interventions before the Sykes-Picot agreement? This study argues that the history of Middle Eastern border formation is not only an international one but also involves many aspects that have not widely been taken into consideration. In doing so, this paper adopts a critical historical perspective to analyze the evolution of Middle Eastern borders. This paper proposes a three-tracked evolutionary analytical framework (frontiers, boundaries, borders) to analyze the emergence of borders and applies it to the emergence of Ottoman territoriality. This study concludes that the Sykes-Picot agreement is only one, complementary part of a long process in the emergence of Middle Eastern geopolitics.
\end{abstract}

Keywords: Ottoman territoriality, Sykes-Picot Agreement, Middle Eastern borders, border studies

\section{Introduction}

In November 1915, Mark Sykes, advisor to British Secretary of State for War Lord Kitchener, and French former consul in Beirut François Georges Picot were tasked by their respective governments to craft an acceptable post-war partition map for the Middle East. Keeping all the interests and considerations of their governments in mind, Mark Sykes and François Georges Picot reached an agreement in January 1916 about the division of the Ottoman Arab territories, and with Russia's approval in May 1916, Sykes and Picot finalized their agreement for establishing zones of influence in the region. ${ }^{1}$ Although the terms agreed on by Sykes and Picot and exchanged by the two governments did not turn into a real agreement and were ultimately further modified by other arrangements, they were highly instrumental in influencing the current borders of the Middle Eastern states.

\footnotetext{
Ali Murat Kurşun, PhD Candidate, Department of International Politics, Aberystwyth University, UK. Email: alimuratkursun@ gmail.com. (D) https://orcid.org/0000-0003-4117-8078.

Eugene Rogan, “A Century After Sykes-Picot,” Cairo Review, 2015, 102, https://cairoreview-b23.kxcdn.com/wp-content/ uploads/2015/10/CR19-Rogan.pdf.
} 
The explanations and recommendations about the post-Arab Spring Middle Eastern order have been primarily constructed upon the differing narratives of the Sykes-Picot arrangements. While the overwhelming bulk of the discussions blamed the Sykes-Picot order as the main source of the contemporary quagmire in which the Middle East struggles, the nascent actors of the post-Arab Spring chessboard have also asserted their commitment to wiping out the traces of the legacy of the 1916 Sykes-Picot Agreement. The Sykes-Picot metaphor has incrementally become firmly associated with almost all the geopolitical predicaments the Middle Eastern states have had to face. Behind the emergence of the Sykes-Picot myth as a springboard for these debates and analyses lays a two-fold argumentation about the order believed to be established by the same agreement. The first part involves problematizing Sykes-Picot as having drawn "artificial" borders dividing societies that were once united, into different political structures. The second part stresses the method the Sykes-Picot agreement followed rather than its consequences, and argues that it was a "top-down" implementation of territorial arrangements that failed to take local realities into consideration.

Departing from the above arguments, a recently emerged popular literature has started to challenge this one-dimensional perception about the formation of the modern Middle Eastern borders by arguing that there is not only the international aspect embodied in the SykesPicot agreement but rather there is the combination of a series of domestic, regional and international factors that together set the ground for the formation of the modern Middle Eastern territorial order. However, despite these recent popular studies' positive steps in revealing the historical continuity of the interplay between local, regional and international factors, they are mostly either specific case studies that chronologically analyze the historical evolution of specific Middle Eastern borders from a historical perspective, or speculative essays that do not provide deeper insights. ${ }^{2}$

Against this backdrop, it seems to be relevant to delve into the historical interplay between domestic, regional and international factors that actually constitute the background of the formation of the Sykes-Picot order from a theoretical and historical perspective to understand the validity of the above-mentioned arguments. This study argues that it is not only the Sykes-Picot Agreement that formed the geopolitical order of the modern Middle East but rather both the domestic and other regional and international arrangements that had long before started to pave the way for the formation of the modern Middle Eastern borders, leaving the Sykes-Picot Agreement as one of the subsequent phases of the evolution.

Departing from this hypothesis, this study mainly addresses the following primary research questions: How did the interplay of the array of domestic, regional, and international developments lay the groundwork for the formation of the Sykes-Picot territorial order?

\footnotetext{
2 Pınar Bilgin, "Thinking Postcolonially about the Middle East: Two Moments of Anti-Eurocentric Critique" (Center for Mellemoststudier, June 2016); Pinar Bilgin, "What Is the Point about Sykes-Picot?," Global Affairs 2, no. 3 (May 26, 2016): 355-59, doi: 10.1080/23340460.2016.1236518; Nick Danforth, "Stop Blaming Colonial Borders for the Middle East's Problems," The Atlantic, September 11, 2013, http://www.theatlantic.com/international/archive/2013/09/stop-blaming-colonial-borders-for-themiddle-easts-problems/279561/; Adam Garfinkle, "The Fall of Empires and the Formation of the Modern Middle East," Orbis 60, no. 2 (2016): 204-16, doi: 10.1016/j.orbis.2016.02.001; Rashid Khalidi, "The Persistence of the Sykes-Picot Frontiers in the Middle East," London Review of International Law 4, no. 2 (July 2016): 347-57, doi: 10.1093/lril/lrw019; Elias Muhanna, "Iraq and Syria's Poetic Borders," The New Yorker, August 13, 2014, http://www.newyorker.com/books/page-turner/iraq-syria-poetic-imagination; Marina Ottaway, "Learning from Sykes-Picot," Middle East Program Occasional Paper Series (Washington, DC: Wilson Center, 2015), https://www.wilsoncenter.org/publication/learning-sykes-picot; David Siddhartha Patel, "Repartitioning the Sykes-Picot Middle East? Debunking Three Myths," Middle East Brief (Crown Center for Middle East Studies, Brandeis University, November 2016), https://www.brandeis.edu/crown/publications/meb/MEB103.pdf; Gareth Stansfield, "The Remaking of Syria, Iraq and the Wider Middle East," RUSI, July, 2013, https://rusi.org/sites/default/files/201307_bp_the_remaking_of_syria_iraq_and_the_wider_ middle_east_final.pdf.
} 
What was the nature of the administrative structure and regional divisions before the SykesPicot Agreement and to which border categorizations did these structures correspond? Was the Sykes-Picot Agreement the only international intervention that affected the borders of the region or were there other international interventions before the Sykes-Picot agreement?

To explore these questions, this paper adopts a critical historical perspective in analyzing the evolution of the Middle Eastern borders. In doing so, this paper proposes an evolutionary analytical framework to analyze the emergence of borders by looking at the process from the perspectives of frontiers, boundaries, and borders. In this regard, this study attempts to contribute to the ongoing literature about the geopolitics of the Middle East and particularly the Sykes-Picot myth by putting a border studies perspective at the core of its narrative.

The first section of this study will evaluate the theoretical/definitional discussions regarding the borders and will put them into an evolutionary perspective. The second section will delve into the evolution of Ottoman territoriality from a border studies perspective to explain the background of the emergence of modern Middle Eastern geopolitics. The next sections will deconstruct the Sykes-Picot order by looking at the domestic, regional, and international developments that paved the way for the contemporary borders. The concluding section highlights the continuations in the historical domestic and international borders and partitions put forward by Sykes-Picot.

\section{A Three-Pronged Evolutionary Typology of Borders: Frontiers, Boundaries, and Borders}

Borders represent the end-point of states' common identities and values while outside of these borders this harmony disappears. As argued by Minca and Vaughan-Williams, borders help states to 'spatialize the political' and thus provide them with the ability to transform their geopolitical imaginations into more concrete and manageable beings ${ }^{3}$. Indeed, as borders create a physical limitation of a sovereign's authority, they both physically divide societies into opposing entities and are themselves also created by those same opposing entities. However, although borders in general are products of dichotomies and at the same time represent a dichotomy or opposition between the adjacent entities themselves, they also serve to reveal and create a more concrete and coherent "reality" inside them. ${ }^{4}$

It is an acknowledged fact that even the first rudimental forms of social structures, i.e. tribes, had an elemental understanding of territoriality mainly embodied in undefined zones rather than defined and well-established areas, and would be later developed further in line with the maturing of political organization. ${ }^{5}$ The historical examples of the Chinese and Roman empires have been utilized to prove the literature's emphasis on the causal relation between political maturity and the emergence of borders. Indeed, these historical cases reveal the transition towards borders as fixed barriers rather than unfixed and undefined vague zones. For instance, as Elden argued, the experience of ancient Greece showed that in this earliest example, the boundaries between polies were somewhat known but not strictly divided; rather there were vast lands between the cities. However, the example of the Roman territorial system demonstrated the emergence of the frontier understanding within the idea

3 Claudio Minca and Nick Vaughan-Williams, "Carl Schmitt and the Concept of the Border," Geopolitics 17, no. 4 (October 1, 2012): 759-61,doi: 10.1080/14650045.2012.660578

4 Muhanna, "Iraq and Syria's Poetic Borders."

Stephen B. Jones, "Boundary Concepts in the Setting of Place and Time," Annals of the Association of American Geographers 49 , no. 3 (1959): 242 
of terra nullius / empty land. ${ }^{6}$

Early literature on geopolitics has portrayed borders as the territorial representations or "manifestations" of states. ${ }^{7}$ The French revolution and the rising trend of rationalism in philosophical thinking was also echoed in geopolitical writings, which began to think rationally on natural borders before being opposed by the German understanding of national borders. ${ }^{8}$ The classical geopolitical writings and their emphasis on borders took shape around the idea of preventing undesirable conflicts by establishing or redrawing more proper borders between neighbor states. These works paid attention to borders in a more functional way but did not intend to make conceptual discussions on the terminology of borders and mainly used the various terms of frontier, border and boundary interchangeably. However, more detailed and conceptual works have argued that these terms represent different meanings and notions. For instance, while describing surveys along the southern borders of Afghanistan in 1897, A. H. McMahon used the three different terms intentionally: frontier, border, and boundary. McMahon wrote that "the southern border of Afghanistan from the Gomal river to the Persian frontier", but "The Koh-i-Malik-Siah mountain marks the southern point of the boundary between Afghanistan and Persia, as agreed by those two governments" (italics mine). ${ }^{9}$ In these sentences, McMahon intentionally made a differentiation between the terms border, frontier and boundary, describing a river as a "border", an undefined area towards Persia as a frontier, and the result of an agreement as a boundary.

\subsection{Frontiers as indefinite zones of transition}

Four years before McMahon published his surveys in Afghanistan, in an essay submitted to the American Historical Association in 1893, the famous American historian Frederick Jackson Turner examined the role of the "frontier" in American history and argued that it was the frontier that drove the fate of America. His conceptualization of frontier considers frontiers to be the layers of a progression and the junction between the civilized and the uncivilized. ${ }^{10}$ Therefore, these frontiers represent the direction towards which the expansion should move. Because they represent the line between the civilized and the uncivilized, they should be taken under control by a progressive actor and "tamed". ${ }^{11}$ Prescott drew attention to the fact that, apart from using the term in its political sense, political geographers also use the term in order to refer to the "zone" between the settled and the unsettled. ${ }^{12}$ Thus, there appears two categorizations for frontiers: political frontiers and settlement frontiers. Newman and Paasi argued that political frontiers are different from settlement frontiers in the sense that political frontiers are encompassed by "international boundaries" whereas settlement frontiers separate the unoccupied and the unpopulated areas from the populated and established areas within

6 Stuart Elden, "Why Is the World Divided Territorially?," in Global Politics: A New Introduction, ed. Jenny Edkins and Maja Zehfuss, Second edition (Milton Park, Abingdon, Oxon: Routledge, 2014), 226-27, http://eu.alma.exlibrisgroup.com/view/action/ uresolver.do?operation=resolveService\&package_service_id $=3039366920002418 \&$ institutionId $=2418$ \&customerId $=2415$.

David Newman and Anssi Paasi, "Fences and Neighbours in the Postmodern World: Boundary Narratives in Political Geography," Progress in Human Geography 22, no. 2 (1998): 187.

8 Jones, "Boundary Concepts in the Setting of Place and Time," 248.

A. H. McMahon, "The Southern Borderlands of Afghanistan," The Geographical Journal 9, no. 4 (1897): 393, doi: $10.2307 / 1774479$.

${ }^{10}$ K. J. Rankin and Richard N. Schofield, "The Troubled Historiography of Classical Boundary Terminology," in Revised Version of a Paper Presented at the 30th Congress of the International Geographical Union, Glasgow, Scotland, 15-20 August 2004 (University College Dublin. Institute for British-Irish Studies, 2004), 4, http://researchrepository.ucd.ie/handle/10197/2245.

11 Newman and Paasi, "Fences and Neighbours in the Postmodern World," 189.

12 J. R. V. Prescott, Political Frontiers and Boundaries, 2nd ed. (Abingdon: Routledge, 2015), 36. 
the territories of a given state. ${ }^{13}$ Malcom Anderson conceptualized frontiers as international boundaries, while Ladis Kristof made a clearer conceptualization of frontiers, describing them not as restriction lines but as open and directed towards the outside; since they are at the edges of the states they represent a "zone of transition". ${ }^{14}$ In sum, frontiers are permeable zones for both the insiders and the outsiders; in some cases, they divide the uninhabited and settled areas, and in other cases they play a facilitator role for transition, with their open, indefinite and moveable characteristics.

\subsection{Boundaries as fixed lines of separation}

Starting from the $17^{\text {th }}-18^{\text {th }}$ centuries and intensifying in the $19^{\text {th }}-20^{\text {th }}$ centuries, the indefinite zones of transitions, i.e. frontiers, began to undergo a process of transformation. These indefinite zones started to become more definite, and were transformed into 'lines of separation'. These lines or boundaries differed from frontiers in the sense that they were definite, recognized, and agreed upon. Thus, 'boundaries' can be understood as well-established formations in comparison with 'frontiers'. While frontiers are directed towards the outside, boundaries are "inner-oriented", legally defined and accurate. ${ }^{15}$ Custred drew attention to one of the most important characteristics of boundaries, that they are drawn in a way that they are certain, and that they designate the end-point of a state's landholding. ${ }^{16}$ While the formation of frontiers take shape according to inhabitation, the formation of boundaries is based more on politics and is state-centered. During the process of boundary formation, the understanding of the territoriality of different societies is constituted in both a physical and discursive manner in which the state plays an important role. ${ }^{17}$

\subsection{Borders as multiplex social and political institutions}

Borders present an overarching conceptualization and understanding that involves different types of territorial and social constructions in an integrated way. In this sense, it can be argued that the term border refers to a territorial notion that is mobile, extensive and includes social realities. Therefore, borders are not only the delimited lines on maps and agreements but also the processes by which these delimited and agreed lines become actual with the interactions and the effects of the societies in/outside of the border. ${ }^{18}$ Thus, whether it is a legal and strict line like boundaries or a broader social phenomenon like borders, the main purpose of such entities is to legally and socially create divisions in order to ensure differentiated systems that maintain their legitimate sovereignties. For instance, Gasparini described borders as representations of the "shared end of the system," dividing the sphere of sovereignty at a national level. ${ }^{19}$ In the words of well-known border studies scholar Emmanuel Brunet-Jailly, borders are "about people; and for most settled territories that are predominantly about inclusion and exclusion, they are woven into varied cultural, economic

\footnotetext{
13 Newman and Paasi, "Fences and Neighbours in the Postmodern World," 189.

14 Rankin and Schofield, "The Troubled Historiography of Classical Boundary Terminology," 1-3.

15 Rankin and Schofield, 3.

${ }^{16}$ Glynn Custred, "The Linguistic Consequences of Boundaries, Borderlands, and Frontiers," Journal of Borderlands Studies 26, no. 3 (December 1, 2011): 265, https://doi.org/10.1080/08865655.2011.675716.

17 Anssi Paasi, “Generations and the 'Development' of Border Studies," Geopolitics 10, no. 4 (December 1, 2005): 669, doi: $10.1080 / 14650040500318563$.

18 David Newman, "On Borders and Power: A Theoretical Framework," Journal of Borderlands Studies 18, no. 1 (March 2003): 15, https://doi.org/10.1080/08865655.2003.9695598.

19 Alberto Gasparini, "Belonging and Identity in the European Border Towns: Self-Centered Borders, Hetero-Centered Borders," Journal of Borderlands Studies 29, no. 2 (April 3, 2014): 167, doi: 10.1080/08865655.2014.916067.
} 
and political fabrics. ${ }^{20}$ Bounded territories and borderlands are the outcome of the continual interactions and intersections between the actions of people (agency) within the constraints and limits placed by contextual and structural factors (structure)". Similarly, David Newman argued that borders as institutions are the mechanisims that decide the included and excluded based on legal rules, which could be strict or flexible. ${ }^{21}$ In sum, the 'border' concept presents an integral and comprehensive perception that holistically involves existential and functional aspects.

A further important classification regarding border making is the difference between borders on a map and borders on the surface, i.e. delimitation and demarcation. It can be argued that the conceptual differentiation between the practices of delimitation and demarcation is actually a modern development that emerged in the late $19^{\text {th }}$ century. Delimitation can be defined as the process, mostly on paper, of identifying, designating and specifying of a "boundary site", while demarcation is the process of practically applying these delimited lines on the ground..$^{22}$ The boundary delimited on the map may differ from the border demarcated on the surface, and in some cases, a territory may actually be the product of a mapping practice. Winichakul, for example, introduced the term "geo-body" to explain the process of creating nations and territories through mapping. ${ }^{23}$

\section{The Evolution of the Ottoman Territoriality: A Border Studies Perspective}

Before delving into the Ottoman case, a short classification of 'territory' should be provided. The mainstream argument in the literature is to portray territory either in its relation to the state or in its relation to a set of actions. In other words, territory is conceptualized either as a consequence of the existence of a state or as part of a strategy. ${ }^{24}$ Territory is by nature an ontological component of a state, i.e. without a territory it is not possible to think of a state. However, territory takes on a new meaning along with the strategic aspirations of a given state. In terms of strategy, territory is related to the expansion or shrinking of a given state's lands. It is thus about a state's relations with its neighbors, whereas the first perspective is more related to domestic arrangements. In this article the Ottoman case is analyzed from the perspective of the first classification, that is, territorial evolution in relation to the 'state' of the Ottoman Empire, not from a behavioral/strategical perspective. Moreover, as Goettlich argued, the understanding here is based on the "linearization of borders" that established the modern understanding of the term of territoriality, rather than the limited focus on sovereignty. ${ }^{25}$ Therefore the main rationale behind the following discussion is to show the link between the Ottoman territorial administration with regard to the broader understanding of sovereignty and the later developments of modern boundary making. Since this is not primarily a historical study, it does not delve into detail and instead uses an analytical narrative aiming to explain the history of the borders by applying the terminology

${ }^{20}$ Emmanuel Brunet-Jailly, "Special Section: Borders, Borderlands and Theory: An Introduction," Geopolitics 16, no. 1 (January 31, 2011): 3, doi: 10.1080/14650045.2010.493765.

21 Newman, "On Borders and Power," 14-15.

22 Prescott, Political Frontiers and Boundaries, 69.

${ }^{23}$ Winichakul demonstrated in the example of Siam that nationhood may be created on maps. However, this study does not take this view in the example of the Middle East, but rather tries to demonstrate the interplay between various factors. Thongchai Winichakul, Siam Mapped: A History of the Geo-Body of a Nation (University of Hawaii Press, 1994).

${ }^{24}$ Stuart Elden, "Thinking Territory Historically," Geopolitics 15, no. 4 (November 19, 2010): 757, doi: $10.1080 / 14650041003717517$

${ }^{25}$ Kerry Goettlich, "The Rise of Linear Borders in World Politics," European Journal of International Relations (March 16, 2018), doi: $10.1177 / 1354066118760991$ 
and conceptualizations explained in the previous section.

The Ottoman Empire took control over the regions of Syria, Iraq and Anatolia starting in the beginning of the $16^{\text {th }}$ century (1516). In fact, although the geographical and human conditions in the Middle East had created some borders, in Islamic societies sovereignty was not based on land but on people. Therefore, while the location of the sovereign would become the center, anyone that recognized this sovereignty would be acknowledged as a part of this center without any conditions with regards to boundaries. Subjects accepted as Dar al Islam (Abode of Islam) the geographies governed by Muslim rulers or where Islamic rules were valid. Therefore, they were far from a real understanding of boundaries. Theoretically, they would see regions accepted as Dar al Islam as a whole within one border. As Abbas Kelider argues, despite being from different countries and ethnicities, Islamic societies saw their Islamic identity as their national identity. ${ }^{26}$ The same cannot be said for the non-Muslim subjects of the previous Islamic empires, however the Ottoman millet system attached importance to their religious identity so that they also perceived their religious identity as part of their national identities. In the Ottoman case, with the beginning of the empire's shrinkage in the $18^{\text {th }}$ century, a transformation and change took place in the reverse direction and a new administrative system based on different divisions such as eyalet (province), vilayet (governorate), hadd-i fasıl (border line) and tahdid-i hudud (delimitation) started to emerge.

\subsection{Eyalets as frontiers}

In early Ottoman sources, Ottoman administrative divisions were described mainly in connection with the ruler. In the classical era, the rulers of large areas were called beylerbeyi (governor). Even though this administrative division was reflected in the commanders appointed to that area, they assumed the name of that area as their title, eg. the Beylerbeyi of Aleppo, Damascus, Saida, etc. Therefore, their powers were naturally limited to the area assigned to them. These beylerbeyliks outlined the edges and the defense of border areas. ${ }^{27}$ Herein, it is possible to argue that the beylerbeylik system corresponded well to the frontier concept explained above, in that they were mobile while not having definite limits and mostly protected by military units.

Selim I founded the Arab province that included Syria, Palestine, Egypt and Hijaz, the Alâüddevle province (conquered in 1515) and the Diyarbekir province (conquered in 1517, first tahrir in 1518). These provinces were subsequently divided into sanjaks-- small units of administrative districts placed under vilayets. As of 1520, the Arab Province had fifteen sanjaks. ${ }^{28}$ It can be said that the provinces represented a flexible frontier system given that the system was not fully settled around these dates. In fact, this system began to shift again after the 1530s. The sovereignty established over Iraq on the one hand, and the new structures founded in the seas and North Africa (excluding Egypt) on the other hand, created flexible territorial limits in the context of frontiers. After the Arab regions came under Ottoman control, the Arab Province was created to include modern day Syria, Palestine, Egypt and Hijaz (part of present-day Saudi Arabia). The changes in the territories of the empire and the needs mainly stemming from taxation later prompted the rearrangement of

\footnotetext{
${ }^{26}$ Abbas Kelidar, "States without Foundations: The Political Evolution of State and Society in the Arab East," Journal of Contemporary History 28, no. 2 (1993): 316.

27 Halil İnalcik, "Eyalet," İslam Ansiklopedisi (TDV İslam Araştırmaları Merkezi, 1995), 549, http://www.islamansiklopedisi. info/dia/pdf/c11/c110350.pdf.

28 İnalcik, "Eyalet," 549.
} 
the Arab Province. To this end, Aleppo, Damascus and Egypt were organized into separate beylerbeyliks. The narrowing and expanding boundaries during the creation of the Damascus Eyalet throughout the first half of the $16^{\text {th }}$ century is a good example of the emergence of flexible eyalet borders. Even though there were no major changes, it is possible to observe six changes to the Damascus Eyalet's limits between when the Ottomans took over that region and 1565. For example, the Anatolian cities of Adana, Urfa, Antakya and Malatya were part of the Damascus Eyalet in 1522 but in 1565 the eyalet was severely narrowed, coming much closer to today's borders. On the other hand, the territory of modern-day Palestine/Israel, Jordan and parts of Lebanon were kept in the Damascus Eyalet. Beginning in 1549, Aleppo was taken out of the Damascus Eyalet and made an eyalet on its own while some cities in Anatolia removed from the Damascus Eyalet were included in the Aleppo Eyalet.

In the beginning of the $17^{\text {th }}$ century, the Empire had 32 eyalets under the responsibility of almost the same number of beylerbeyliks, however it should be noted that these numbers were changing constantly and no historical account is able to show an exact number. In this context, the Eyalets of Damascus, Tripoli, Aleppo and Raqqa were founded in the region. In sum, it is possible to assume that eyalets determined symbolic and administrative needs and also served as frontiers. They served as frontiers since most of the above changes and delineations were results of the empire's expansion and the resulting need for better territorial administration. As the territories expanded, need for further organization of the eyalets emerged and this is a clear demonstration of eyalets as movable frontiers.

\subsection{Vilayets as boundaries}

With the $19^{\text {th }}$ century, the Ottoman Sultan Mahmud II wanted to make a new eyalet arrangement to rebuild the central power of the state and his own authority. Beginning in 1812 , he reorganized former eyalets into "müssiriyet", taking military and financial obligations into account. ${ }^{29}$ Mahmud II's radical rearrangements abolished the timar system, the empire's traditional land regime. At this point, the Tanzimat projected a new land regime. This was the aim of the Ottoman Land Code, which was announced after the Tanzimat. ${ }^{30}$ When all these developments proved to be insufficient, the administration of the Ottoman countryside was rearranged with the provinces charter (vilayetler nizamnamesi), which was put into application in 1864 and 1871 . With this rearrangement, vilayets replaced eyalets and their geographic boundaries were made clearer. The country was divided into vilayets, vilayets into mutasarrifates (lieutenant governorship), mutasarrifates into kazas (district) and kazas into nahiyes (sub-district) and villages. This administrative division was mentioned in detail in the empire's yearbooks (Salname) and shown clearly on new maps. Just like eyalets, vilayet boundaries experienced some changes from time to time but the overall arrangements remained the same until the collapse of the empire. In a way, these quick changes were a signal of a move towards the boundary concept, which is based on fixed and agreed borders.

Following the Empire's 1864 arrangements, more definite vilayet boundaries were drawn and every vilayet came under the rule of a governor. One of the most notable things here is that when the Syria Province was established, the ancient word 'Syria' was also used by the Ottomans to replace the Damascus Eyalet. Iraq as a region was always referred to as Southern

\footnotetext{
29 İnalcik, "Eyalet," 550.

30 İlber Ortaylı, Imparatorluḡun en uzun yüzyllı (Timaş Yayınları, 2008), 245-46.
} 
Iraq (Iraq-i Arab-Arabic Iraq) $)^{31}$ and was comprised of the Baghdad and Basra vilayets. Mosul in the north was always thought of as an entity independent from Iraq. After the publication of the 1864 charter and between the time of the establishment of the new vilayets and 1918, the new Syria Vilayet was comprised of four sanjaks: the Sanjaks of Damascus, Hama, Hauran and Maan (Karak). The boundaries of the Syria vilayet were defined as an area that included the surroundings of modern-day Jordan and Damascus, with Mount Lebanon being kept outside of Syria as a privileged sanjak. Long after the 1864 arrangements, the Beirut vilayet was founded as an independent area from the Damascus eyalet. It included a part of modern-day Syria as well as mandate Palestine, and was comprised of five sanjaks: Beirut, Acre, Tripoli, Latakia and Belka (Nablus). The Jerusalem Sanjak was directly governed from Istanbul because of its religious peculiarities. It was comprised of its center, the Jerusalem district, and the districts of Jaffa, Gaza and Halilurrahman (Hebron). ${ }^{32}$ Here, the most important conclusion to be drawn from these developments is the fact that the emergence of eyalets as well-defined territorial units happened at a time when the idea of further expansion had come to an end. Thus, after the possibility of further expansion disappeared, well defined, stable boundaries for these territorial units were needed, not moving frontiers. The Ottomans thus devised a new land regime and reorganized the territorial units accordingly so that the boundaries of each unit would become more definite. These agreed upon boundaries remained largely unchanged until the collapse of the empire.

\section{Deconstructing the Sykes-Picot Order: Domestic, Regional, and International Factors}

Moving on chronologically, it can be argued that modern Middle Eastern borders are not only the result of the Sykes-Picot agreement, but rather the outcome of the interaction between specific domestic, regional, and international developments. In this section the following developments with regards to the Middle Eastern borders will be analyzed: Domestic Factors (the Egyptian crisis and the Aqaba border, the Mount Lebanon Concession, and the sacred boundaries of Palestine); Regional Factors (the Persian Gulf, the Ottoman-Iranian Border, and border arrangements in Yemen); International Factors (the Sykes-Picot Agreement).

\subsection{The Egyptian crisis and drawing of the Aqaba border}

The Egyptian Question began with the French invasion in 1789 and developed initially as a domestic issue before turning into an international problem and leading to discussions over the Egypt-Syria border. ${ }^{33}$ The Governor of Egypt, Muhammad Ali, expanded his influence over large areas, taking advantage of the special circumstances of the Ottoman Empire. Creating trouble for the Ottoman Empire after their emergence in middle Arabia, the Wahhabis captured places sacred for Muslims. Muhammad Ali was tasked with removing the Wahhabis from these areas. His son Ibrahim Pasha's success against the Wahhabis in 1818 resulted in Muhammad Ali's seizure of coastal parts of the Ottoman-held Gulf of Basra as well as the Hejaz. ${ }^{34}$ He later expanded his rule around Sudan as well. With the help of the

${ }^{31}$ Fred Halliday, The Middle East in International Relations: Power, Politics and Ideology (Cambridge University Press, 2005), 77.

32 Devlet-i Aliyye-i Osmaniye'nin 1313 senesine mahsus istatistik-i umumiyesidir (İstanbul: Nezaret-i Umur-i Ticaret ve Nafia, 1316), 2-4.

33 Peter Partner, A Short Political Guide to the Arab World (Literary Licensing, LLC, 1960), 19-20.

${ }^{34}$ Zekeriya Kurşun, Necid ve Ahsa'da Osmanlı hâkimiyeti: Vehhabî hareketi ve Suud Devleti'nin ortaya çıkışı (Ankara: Türk Tarih Kurumu, 1998) 
French, Muhammad Ali's army became a major threat to the central authority while at the same time being an indispensable force on its behalf. In fact, the Ottoman government asked for Muhammad Ali's help during the Greek rebellion, for which he demanded to rule over the Syria province as well. The Ottoman government on the other hand, which sought to unite Egypt and Syria and create an independent state, did not grant this wish. Nevertheless this conflict continued to grow and turned into a crisis in 1832. Using the failure to return fugitives that fled to Acre as a pretext, Ibrahim Pasha besieged Acre Castle and did not comply with Istanbul's request to lift the siege. Ibrahim Pasha was able to advance as far as Kütahya in Western Anatolia. In return for Ibrahim Pasha's withdrawal from Anatolia, the rule of the Damascus and Hejaz eyalets, which include Saida, Tripoli and Jerusalem, was given to the Muhammad Ali Pasha. Ibrahim Pasha's rule over the province of Syria lasted nearly 10 years. Muhammad Ali Pasha sent a diplomatic note to the European states in an aborted attempt to enlist them to help him gain independence for Egypt. He then met with consuls in Alexandria with a new proposal that the Ottomans allow his family to inherit the areas he ruled. The new sultan, Abdülmecid, sought to reconcile with Muhammad Ali Pasha by pardoning him and accepting the inheritance claim over Egypt. Nevertheless, Muhammad Ali Pasha also demanded inheritance of Syria, which he had ruled for ten years. In the meantime, foreign states completed their talks and prepared the London Protocol, dated 15 July 1840, that would allow Muhammad Ali Pasha's family to inherit Egypt. After long discussions, a decree from the Istanbul government, based on the London Protocol, granted autonomy to Egypt in 1841, and the boundaries were decided in a similar way to delimitation. Over the course of time, because the boundaries were not demarcated on the ground, another disagreement emerged in 1904 in the Aqaba area, located now on the Israeli border. With an agreement reached on 1 October 1906, a demarcation was made in this region for the first time. Under the agreement, borders were defined with poles, leaving Aqaba in Ottoman territory and Taba in Egypt.

\subsection{The Mount Lebanon concession}

The region remained calm during periods of strong governors but problems reemerged whenever state authority appeared weak. Ibrahim Pasha's rule in the region, despite being a de facto situation viewed by the Ottomans as illegitimate, was a precursor to new problems. Both Ibrahim Pasha's apprehensions about traditional prerogatives and foreign states' interference increased clashes in the region and caused the 1840 Druze-Maronite problem. ${ }^{35}$ The clashes between Christian Maronites (mostly peasants) and Abrahamic Druzes (mostly land owners) continued until 1860 and resulted in a civil war in which tens of thousands Christian Maronites were killed by Druzes. The Europeans, particularly France, were keen on backing Maronite rights and supported them. On the other hand, the Ottoman's opendoor policy after the 1838 Ottoman-British agreement gave foreign states a large radius for action. ${ }^{36}$ Foreign states' economic relations with Mount Lebanon and Beirut advanced and they began to apply political pressure. The Ottoman Empire, taking the European states' demands into account, came up with a solution in 1842 that projected the division of the region between two kazas (district governorships). By choosing a governor from both the Druze and Maronite populations, the Ottomans created a divided administration. However, this geographical division was far from a lasting solution as the Maronites were

\footnotetext{
35 Fawwaz Traboulsi, A History of Modern Lebanon, 2 edition (London : New York: Pluto Press, 2012), 12-13.
}

36 Engin Akarli, The Long Peace: Ottoman Lebanon, 1861-1920 (University of California Press, 1993), 29. 
not geographically concentrated in one region in Lebanon. District governors reported to the governor of Saida and were seen as community leaders with undefined administrative powers.

Amidst diplomatic pressure coming from Britain, France, Russia, Prussia and Austria, the Ottoman Foreign Minister Shekib Effendi issued a regulation (the Reglement of Shekib Effendi) in September 1846 and announced that the current situation would continue in Lebanon (a Christian district governor in the north and a Druze district governor in the south, both reporting to the Beirut centric Saida Vilayet). This new regulation more clearly defined the new administrative structure in an 8-point program explaining the operations of two district governors and their powers. However, the program did not mention boundaries. Yet, it is possible that the boundaries of two districts were the traditional boundaries accepted in the past. This means that the Ottoman Empire avoided creating new problems by demarcating two districts. On the other hand, the traditional boundaries were defined in accordance with the areas where both sides (Maronites and Druzes) were the majority, meaning it was defined according to demographic distribution.

In 1860, clashes recommenced between the Druzes and Maronites, resulting in further international intervention. Without going into details, it is important to note that these events resulted in the most significant foreign intervention in the region during the Ottoman era. Foreign states participating in the Paris protocol proposed to the Ottomans that Mount Lebanon get privileges before they would send representatives to Beirut to observe the new arrangements on the ground. Their five-point proposal suggested transforming the two-district system into a more unified mutasarrifate, and projected how the administrative structure would operate. Per the new proposal, Mount Lebanon would become a privileged sanjak within the Ottoman administrative structure and a non-local Christian mutasarrif would be appointed. The sanjak would be divided into seven districts, each having local district governors, taking the demographic majority into account. Even though mutasarrifate's administrative division was clearly outlined, there were no mentions of boundaries, just as in the reglement of Shekib Effendi. While the mutasarrifate would be a sub-unit part of the Damascus vilayet, the government in Istanbul wanted the mutasarrifate to report directly to them. These proposals were put into effect with an additional protocol signed on 9 June 1861 and revised in the Lebanon Charter of 1864 following review. This document defined the jurisdiction of officials and how the privileges would be applied and, as has been argued, it ensured a peace that lasted almost half a century. ${ }^{37}$

\subsection{The sacred boundaries of Palestine}

In both Eastern and Western literatures, Palestine was a common term for the area between the Mediterranean Sea in the west and the River of Jordan and the Dead Sea in the east. ${ }^{38}$. In Tuhfetu'l-Kibar fî Esfâr el Bihâr, the $17^{\text {th }}$ century Ottoman source, Katip Çelebi included two Palestine maps. ${ }^{39}$ The first was of the Mediterranean region, showing contemporary Palestine and the Damascus Eyalet as "Arz-l Filistin" (Land of Palestine) in what was most probably the first appearance of the name Palestine in Ottoman maps. The second map, the

\footnotetext{
37 Akarli, The Long Peace,

38 Dima W. Nazer et al., "Water Footprint of the Palestinians in the West Bank," JAWRA Journal of the American Water Resources Association 44, no. 2 (April 2008): 450, doi: 10.1111/j.1752-1688.2008.00174.x.

39 Katib Çelebi, Tuhfet ül-kibâr fi esfâr il-bihâr (Müteferrika, 1729).
} 
İklim-i Ceziretu'l-Arab (Geography of the Arabian Peninsula), had a clearer delimitation for Palestine. In the explanations accompanying the second map, the boundaries of Palestine extended from the Gaza and Jerusalem Liwas in the southwest up to the Sinai Desert, between the Mediterranean Sea and Arish. In the southeast, it extended to the Dead Sea and the River of Jordan. In the north, the border went from the River of Jordan to Kaysariye. ${ }^{40}$ It is possible to argue that these given boundaries were those defined by religious sources, which is why we may call them "sacred boundaries". The administrative structure in the Ottoman era, as discussed before, did not allow for the showing of Palestine's borders clearly, as these lands were a natural part of Syria during the Ottoman period. There were no boundaries to separate it from Syria nor any racial, historical or peripheral obstacles to ensure it. For this reason, Palestine was a part of the Bilad al Sham (Greater Syria) vilayets.

The Ottoman government unified the sanjaks of Jerusalem, Acre and Nablus under the Acre province in 1831 to counter Muhammad Ali Pasha's advances. The boundaries of the area offered to Muhammad Ali Pasha by Sultan Abdulmecid were: from Re's Nafûra until the Mediterranean coast, in the north where the Sisban River meets Lake Tiberias following the western edges of the lake, the side of River Jordan and west of the Dead Sea. In 1872 the Ottoman Empire created a province within the boundaries of the proposal above, independent from Damascus. The new province included Acre, Nablus and Jerusalem. The 1831 arrangements had come out of political necessity while the 1872 arrangements were the result of the new land regime declared in 1864 (which was explained above). The main difference between these two arrangements is related to the position of Jerusalem, which was finally regarded as an independent unit in 1873. The northern boundary of this new province established in 1872 extended to the line separating Acre and Beirut and included all places considered sacred for Jews and Christians, such as Safed, Tiberia, Nazareth, Jerusalem, Bethlehem and Hebron). However, the Ottoman government realized that it would not be possible to administer these areas under one province and therefore abolished this province. In the following year, 1873, Jerusalem became an administrative subordinate of the government in Istanbul. Regardless of the purposes for the administrative arrangements in the areas including the presence of sacred sites, Jerusalem remained the center point of the middle and southern areas even after 1873. The districts of Gaza and Yaffa reported to Jerusalem. Even areas such as Nablus and Nazareth were brought under Jerusalem. There is no doubt that these arrangements made for a stronger argument that this region be an administrative entity independent from its surroundings. Another map published by the Ottoman Eighth Army in 1915 shows more definite borders of Palestine. On this map, Palestine's territory includes Jerusalem, Nablus and Acre, its northern borders extend to Tyre and the Litani River, ${ }^{41}$ and it includes a significant part of the Beirut region. In both the Sykes-Picot agreement and during the British Mandate era, the boundaries of Palestine appeared very similar to the definition of Palestine in the last years of the Ottoman Empire.

\subsection{The Persian Gulf: the 1913 Anglo-Ottoman Agreement}

Since 1903 Britain had been demanding the delimitation and demarcation of the boundaries between the Ottoman territories and the territories under its influence or occupation. To this end, the British presented the Ottomans with a fait accompli in three geographies. The first

\footnotetext{
${ }^{40}$ Çelebi, Tuhfet ül-kibâr.

${ }^{41}$ Filistin Risalesi, 1915.
} 
was in the Red Sea in Yemen, the second was in the Persian Gulf, and the third was along the Ottoman-Iranian border stretching from the Persian Gulf to Doğu Beyazit.

In the $16^{\text {th }}$ century, Ottoman sovereignty stretched as far as Muscat, Oman, however in practice de-facto sovereignty stretched up until 1916 from the coasts of Basra-Kuwait to the area of the present-day United Arab Emirates. There was no fixed boundary between the Ottoman empire and Oman. Nevertheless, as Britain had started to settle in Oman and began expanding its zones of influence to the territories of the Ottoman empire, the boundaries between them started to become meaningful. While the British Raj (British government in India) was obtaining economic concessions (navigation in the Shatt al Arab, Tigris and Euphrates) from the Ottoman empire, they were also trying to restrict Ottoman sovereignty in these regions with unofficial delimitations by making secret agreements with some of the local leaders. As a matter of fact, this rivalry constituted the most important aspect of Ottoman-British relations before the First World War. ${ }^{42}$

The Ottoman Empire, since 1870, with an attempt to turn this situation in its own favor started to implement new arrangements designating its de facto areas of sovereignty. For instance, the Ottomans made their military presence felt in the east of Saudi Arabia and Qatar with a military operation it carried out through Baghdad. ${ }^{43}$ Before this military operation, the Ottomans persuaded the sheikh of Kuwait, Abdullah al Sabah, to connected the sheikhdom to the Baghdad vilayet as a district governorate. Since these regions were considered under the classical understanding of the Ottoman empire, it is possible to portray these arrangements as restorations rather than the creation of new administrative structures. These restorations were needed because the British had been making secret deals with various Arab sheikhdoms on the Persian Gulf and was trying to exert influence against Ottoman sovereignty. Thus the restorations and the military operation ended the possible advance of the British in the Persian Gulf and to some extent limited the British influence. Bahrain, which had recently become a point of concern for the British, and the Muscat Imamate were excluded from these restorations. In fact, local leaders were demanding to be included in these restorations but the Ottoman central administration, considering the possible British objection, excluded in particular Bahrain - although they were claiming it was part of the empire - from these arrangements. ${ }^{44}$ Completed in 1871 , these arrangements also confirmed Ottoman sovereignty over Eastern Saudi Arabia, Kuwait and Qatar. What is important here is that the OttomanBritish struggle for influence had started from this date on and rose to the surface on every occasion.

Herein it is worth highlighting two important developments that escalated tensions. The first was the internationalization of the Mesopotamian oil reserves, and the second was the rapprochement between the Ottomans and the Germans and the German obtainment of the Baghdad railway concession in $1903 .{ }^{45}$ This railway concession was seen by the British as a major threat to both its interests in the Persian Gulf and its presence in India. Added to the existing Ottoman-British rivalry, the possibility of the railway being extended to Kuwait

\footnotetext{
42 Frederick F. Anscombe, The Ottoman Gulf: The Creation of Kuwait, Saudia Arabia, and Qatar (New York: Columbia University Press, 1997), 3.

43 Anscombe, The Ottoman Gulf.

44 Kurşun, Necid ve Ahsa'da Osmanlı Hâkimiyeti: Vehhabî Hareketi ve Suud Devleti'nin Ortaya Çıkışı, 94-98.

45 Ernst Jäckh, Background of the Middle East (Cornell University Press, 1952), 16-17; Ali Okumuş, Osmanlı Coğrafyası'nda petrol mücadelesi: Kalust S. Gülbenkyan ve Türk Petrol Şirketi (İstanbul: Taş Mektep Yayıncılık, 2015), 103-6; Stefanos Yerasimos, Milliyetler ve sınırlar: Balkanlar, Kafkasya ve Ortadoğu (İstanbul: İletișim Yayınları, 1994), 205.
} 
further complicated question and created the necessity of delimiting the boundaries and defining the areas of sovereignty. To this end, the Ottoman and British empires entered into negotiations in 1909 and as a result İbrahim Hakki and Edward Grey signed the AngloOttoman agreement on 29 July 1913. ${ }^{46}$ Although Britain recognized Ottoman sovereignty over eastern Arabia (Ahsa and Qatif) and some parts of Qatar, they considered Kuwait and Bahrain as different cases. Britain was completely rejecting Ottoman sovereignty over Bahrain, and for the Kuwait case, was proposing its recognition as an autonomous entity by drawing definite boundaries. Moreover, the British agreed on Ottoman sovereignty over the emirate of Najd/Saudi and delimited some parts of the Ahsa/Qatif region. The discussions over Kuwait mainly centered on the question of the islands along its coasts. Ultimately, a solution regarding Kuwait's sovereignty was found as Britain recognized the autonomous Qatari government, which was loyal to the Ottomans, in exchange for drawing boundaries for Kuwait that would not be touched by the Ottomans. ${ }^{47}$ These developments in the Persian Gulf were remarkable in the sense that they did not only show the ambiguities of the Ottoman territoriality but also demonstrated the role of borders as multiplex entities. As explained in the theoretical discussion above, unlike frontiers and boundaries, borders are not only related to political and strategic aspects of territoriality but also include economic, social, and cultural levels as well. In this case, the interplay between Anglo-Ottoman political rivalries, the economic developments in the region (oil, railways), and the cultural patterns of the sheikdoms (autonomy) all contributed to the arrangements in the territorial Persian Gulf. Without considering all of these aspects together, it was not possible to came up with these arrangements. Thus, this episode appears to be a good demonstration of the emergence of borders as multiplex entities.

\subsection{Ottoman-Iranian border making and the Istanbul Protocol of 1913}

In 1821, in asserting claims about the Ottoman violation of borders, Iran occupied some cities in eastern Anatolia, such as Bayezid, Bitlis, Mus, and Ercis. In the wake of this, the Ottoman Empire and Iran signed an agreement in 1823 in Erzurum, however this agreement did not bring about a change but rather reconfirmed the terms of the 1746 agreement. ${ }^{48}$ Border issues between the Ottomans and Iran became an international matter along with the rivalry between Russia and Britain over Iranian territories. As a result, a new agreement signed in 1847 in Erzurum called for the establishment of a demarcation commission that would involve British and Russian commissioners as well. The commission worked for four years between 1848 and 1852 and tried to identify the position of the Ottoman Iranian border on the ground. Meanwhile, related work both on maps and on the ground continued, until finally, in 1869 they produced a joint map titled Carte Identique. ${ }^{49}$ Once more, however, British-Russian rivalry over Iran prevented the implemention of this joint map by both parties. Indeed, having an influence over Iranian territories was crucial for Russia's historical strategy of opening towards the south, and thus a British-Russian rivalry in the region became inevitable.

As a consequence of this rivalry, Iran was partitioned into influence zones between Russia

${ }^{46}$ Mahmoud Haddad, "Iraq before World War I: A Case of Anti-European Arab Ottomanism," in The Origins of Arab Nationalism, ed. Rashid Khalidi et al. (New York: Columbia University Press, 1991), 132-33; Zekeriya Kurşun, The Ottomans in Qatar: A History of Anglo-Ottoman Conflicts in the Persian Gulf (The Isis Press, 2002), 124-28.

47 Anscombe, The Ottoman Gulf, 162-64; Kurșun, The Ottomans in Qatar, 128-36; Yerasimos, Milliyetler ve snirlar, 210.

48 Sabri Ateş, Ottoman-Iranian Borderlands: Making a Boundary, 1843-1914 (Cambridge University Press, 2013), 52-57.

49 Pirouz Mojtahed-Zadeh, Boundary Politics and International Boundaries of Iran (Universal-Publishers, 2007), 140. 
and Britain. While Russia held influence over the north of Iran, Britain's influence zone was the south. Taking these into account, the Anglo-Ottoman Convention on 29 July 1913 also touched upon the Ottoman Iranian border and included its delimited maps. Although the Ottomans never exchanged the signed copy of the agreement, the British insisted on its implementation and physical demarcation on the ground. In that vein, Russia was also pressing for clearly demarcating the Ottoman-Iranian border. Finally, on 17 November 1913, the Ottoman Empire and Iran signed the Istanbul protocol, ${ }^{50}$ according to which the remaining non-delimited quarter of the Ottoman-Iranian boundary would be demarcated by a boundary commission. This boundary commission included both Ottoman and Iranian commissioners as well as British and Russian commissioners. ${ }^{51}$ The commissioners started their boundary work from Shatt al Arab and completed their work by demarcating the remaining portion of the Ottoman-Iranian boundary. ${ }^{52}$ Although the Ottoman-Iranian boundary does not have any direct relation with the Sykes-Picot agreement, it became more of an issue since it was the most important demarcation example in the region and was directly related to the British claims over Mesopotamia that would emerge in the subsequent years.

\subsection{Ottoman-British border arrangements in Yemen}

After Britain had settled in India, they began showing great interest in the Arabian peninsula due to its strategic position vis-à-vis the Indian ocean. As a matter of fact, Britain occupied Aden in 1839 on the grounds that its trade had been under threat due to local insurgencies, and attached Aden's administration to Mumbai..$^{53}$ As a response to this occupation, the Ottoman Empire restructured its administration in Yemen in 1872. While the British were engaging in bilateral relations with various tribes in the region in order to exert influence over them, the Ottomans entered negotiations with Britain starting from 1873 and demanded the British not make contact with the local leaders of Nevahi Tis'a around Aden. ${ }^{54}$ This demand was not met by Britain, which instead moved forward on bilateral agreements with various local leaders around the region. ${ }^{55}$ Following these developments, Nevahi Tis'a became the main subject of discussion regarding Ottoman-British boundary arrangements.

The root of these discussions was that as Britain attempted to expand northward in an attempt to preserve its status in Aden, they had to face with the Ottomans. This question was brought to the agenda again and again as British interests in the region grew and as the Germans gained more influence in the Ottoman Empire. Britain's main target was to divide Yemen into two, as North Yemen and South Yemen, and delimitate the boundary between North Yemen and Aden in the south. Throughout history, however, there had never been a boundary separating the north and the south in Yemen but rather there were tribal zones, which were not defined. Furthermore, separating the north and the south in Yemen did not serve any purpose for the Ottoman Empire. However, as Britain repeatedly raised the issue

50 For the full text of the protocol see Melike Sarıkçıoglu, Osmanlı-Iran hudut sorunları 1847-1913 (Türk Tarih Kurumu, 2013), 181-92.

51 Ali Murat Kurşun, ed., Osmanlı Iran sınırından anılar (İstanbul: Taş Mektep Yayıncılık, 2014 ), 4.

52 C. H. D. Ryder, "The Demarcation of the Turco-Persian Boundary in 1913-14," The Geographical Journal 66, no. 3 (1925): 237, doi: $10.2307 / 1782977$.

53 R. J. Gavin, Aden under British Rule, 1839-1967 (Hurst, 1975).

54 Thomas Kühn, "Shaping and Reshaping Colonial Ottomanism: Contesting Boundaries of Difference and Integration in Ottoman Yemen, 1872-1919," Comparative Studies of South Asia, Africa and the Middle East 27, no. 2 (September 18, 2007): 315-31.

55 Ali Akyıldız and Zekeriya Kurşun, eds., Osmanlı Arap coğrafyası ve Avrupa emperyalizmi (İstanbul: Türkiye İş Bankası Kültür Yayınları, 2015), 37-38. 
and pressured for change, the Ottomans had to consent to work on boundary delimitation starting in $1901 .{ }^{56}$ To this end, several boundary commissions were established and meetings were held in the capitals of the two states regarding the boundaries in Yemen. These joint commissions executed several boundary protocols in 1903, 1904 and 1905, and produced delimited maps to be consulted in the demarcation process. The Ottomans attempted to string the question out by bringing up such issues as Yafa, Dali, and Jalila, which ultimately were not solved in the boundary protocols. However, the question of Nevahi Tisa was provided a solution with the application of the 1913 protocols regarding the Persian Gulf. In addition, the Anglo-Ottoman South Yemen boundary agreement was signed on 9 March 1914 in London and came into force with the exchange of the treaty by the two countries on 06 June 1914. ${ }^{57}$ The Ottomans signed this agreement on the condition that it would not make any concessions on the 550-mile square land near the Red Sea. Significantly, the agreement not only delimitated the boundary between North and South Yemen but also set bounds to Ottoman sovereignty in the Red Sea and Persian Gulf. In the end, Britain accepted Ottoman sovereignty over the territories stretching from the Nevahi Tisa boundary to Ujayr in the Persian Gulf (today located in the Eastern Saudi Arabia). In return, Ottoman sovereignty in Aden, Nevahi Tis'a, Hadramawt, Dubai, Abu Dhabi and Muscat was terminated..$^{58}$

\section{Conclusion}

Against the backdrop of domestic and regional factors that paved the way for the formation of today's modern Middle Eastern borders, it is possible to argue that the articles of the Sykes-Picot agreement were a logical follow-up to this process. As the above investigation suggests, previous domestic and regional developments played a role in the delimitation of British and French zones of influence under Sykes-Picot. This is not to say that the SykesPicot agreement was legitimate or that it corresponded perfectly with the local and regional realities, but it is possible to find traces of the previous developments adding a new dimension to discussions about its artificiality or legitimacy.

The Skyes-Picot agreement proposed five different zones of influence and included two indirect influence zones marked as A and B (see map below): 1) French direct control would be introduced over some parts of southeastern Anatolia and the coasts of the Ottoman provinces of Syria, Aleppo and Beirut (blue zone); 2) France would have indirect control over the Arab state that would be established on the interior territories of present-day Syria and northern Iraq, including Mosul (illustrated as A in the map); 3) Britain would directly control the south of Iraq and the western side of the Persian Gulf including Kuwait and the coasts of Basrah; 4) Britain would have indirect control over the Arab state established on the present territories of Jordan, the West of Iraq, and some parts of eastern Arabia (illustrated as B in the map); and 5) an international administration would control Palestine, including present Israel, the West Bank and Gaza. ${ }^{59}$

56 Thomas Kühn, “Ordering the Past of Ottoman Yemen, 1872-1914,” Turcica 34 (2002): 189-220.

57 Fadhl Al-Maghafi, "More than Just a Boundary Dispute: The Regional Geopolitics of Saudi-Yemeni Relations" (SOAS, University of London, 2012), 192, http://eprints.soas.ac.uk/15941/2/Al-Maghafi_3478_vol2.pdf.

58 Akyıldız and Kurşun, Osmanlı Arap coğrafyası, 283-317; Ş Tufan Buzpınar, "Abdülhamid II and Sayyid Fadl Pasha of Hadramawt," The Journal of Ottoman Studies 13, no. 13 (1993): 227-39.

59 John Felton, The Contemporary Middle East: A Documentary History (Washington, D.C: CQ Press, 2008), 13. 


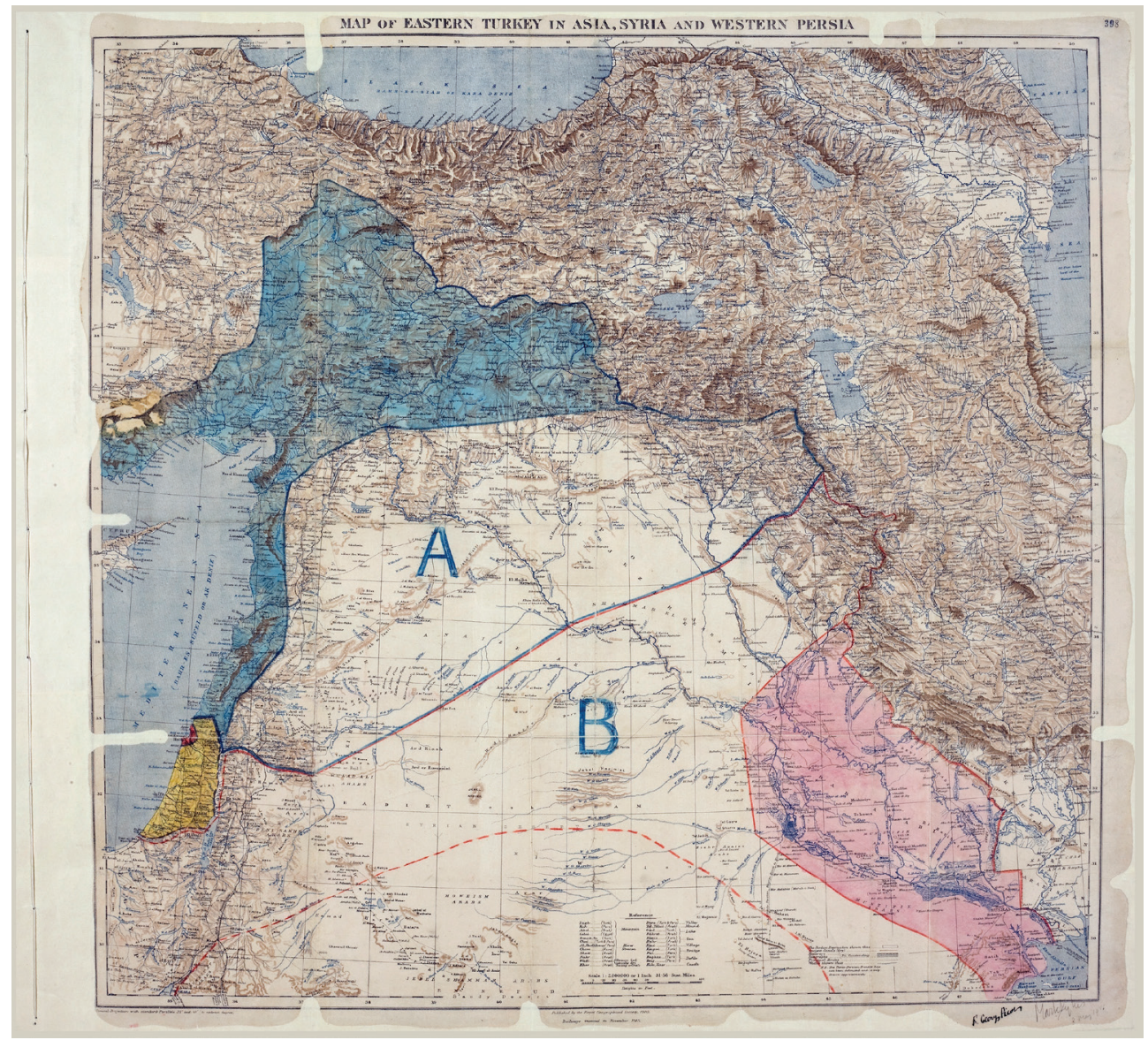

Figure 1. Map of the Sykes-Picot Agreement

These partitions of the Sykes-Picot agreement went along with Britain's and France's historical missions in the region. As was mentioned before, The French had, starting from the $17^{\text {th }}$ century, established ties with the Levant region. They had installed various representatives in the region and founded several powerful consulates, and had an important say in the region's trade relations. On the other hand, France was also enjoying an interventionist position with regard to the crisis of the region as experienced in 1840 and 1860-61. The regions allocated to French direct control covered geographies whose delimitation had before completed after 1864 , such as Aleppo and Syria and the newly emerged vilayet of Beirut. The regions in Anatolia that were allocated to French control were extensions of these geographies, but could also be considered as tactical moves as, in this way, it would be much easier for Britain to distract the French from gaining interest in Mosul.

This planning allowed the creation of the Syrian and Lebanese states in the coming years and the drawing of their boundaries in line with this historical continuity. It would be seen surprising that Mosul was left to French indirect control since the British had been demanding Mosul from the very beginning. Moreover, Britain had strong historical ties to Mosul and had been enjoying navigation on the Tigris river. However, historical continuity seems to again 
play a role here since Mosul was seen as an historical part of Anatolia and it seems that for this reason Sykes and Picot decided to leave Mosul under indirect French control. Another possible justification for this decision might have been the fact that the British army at that time was located far away from Mosul and had been heavily defeated in Kut al Amare.

When the regions under British direct control were evaluated, it was evident that Britain since the beginning of the $19^{\text {th }}$ century had established strong relations with these geographies. Indeed, Britain had signed many protection agreements with several Arab emirates in the Persian Gulf and had in fact started their military operation toward Iraq from these regions. Although Britain was heavily defeated in Kut al Amare when the Sykes-Picot agreement was signed, they were nevertheless able to draw near to Baghdad and the region was under their military control. Historically, Iraq constituted an integrity consisting of the Ottoman Baghdad vilayet, the Basra vilayet, its coasts and the southern regions. Therefore, in consideration of this historical integrity, this region was placed under direct control of Britain as a whole. There was no boundary to be drawn here except for Mosul, since the Ottoman Baghdat and Basrah provinces had long before been well delimited.

The decision of establishing an international administration over Palestine was again stemming from historical reasons. Not only Muslims but also different groups of both Christians and Jews had interests in Palestine. As was discussed in the previous section, the driving factor behind the delimitation of Palestinian borders were the sacred texts. For this reason it was decided to postpone seeking a solution to the Palestinian issue by establishing a provisional international administration.

This study has examined the Sykes-Picot order with an attempt to deconstruct its mythologization by proposing an evolutionary assessment of border understanding. Departing from current discussions on the artificiality of today's Middle Eastern borders, this study took the position that the history of Middle Eastern border formation is not only an international one but involves many aspects that have not yet been taken into consideration.

In doing so, this study first argued that the concept of border can be used as an analytical tool by perceiving it as an evolutionary process under the three-layered category of frontiers, boundaries and borders. Second, this study applied this evolutionary border understanding to the historical Ottoman administrative structure in order to show how the frontier-like eyalets were transformed into more definite boundary-like structures. The main aim behind revealing the evolutionary process behind eyalets and vilayets was to show how the domestic arrangements provided a ground for future arrangements. Third, this study attempted to portray the Sykes-Picot agreement as a complementary part of a long process rather than portraying it as the only reality. To this end, this study categorized different border formation cases within the Ottoman Arab geography on the basis of dominating domestic, regional and international factors. In this regard it tried to cover how the British-French, British-German, and British-Russian rivalries as well as domestic and regional local power struggles had significant impacts on the cases of Aqaba, Lebanon, Palestine, the Persian Gulf, Iran, Yemen, and finally on Sykes-Picot itself.

Indeed, in the evolving tradition of Global History and Global International Relations, the importance of local knowledge and domestic developments as opposed to Euro/Western centric accounts is growing. The geopolitics of the Middle East appear to be one of the most important subjects of this tradition. This study aimed at portraying the Sykes-Picot dominated Middle Eastern geopolitical narrative as being biased. Indeed, both the developments during 
the Ottoman Empire and the realities of the region had already paved the way for the emergence of a regional geopolitical order well before Sykes-Picot. From this perspective, the Sykes-Picot agreement can be portrayed as a complementary or even logical final factor. Indeed, there is no doubt that the Sykes-Picot agreement served to imperial purposes and produced a partition protocol, however, while making that argument, it is not possible to neglect the full realities and experiences regarding the history of the region. 


\section{Bibliography}

Akarli, Engin. The Long Peace: Ottoman Lebanon, 1861-1920. University of California Press, 1993.

Akyıldız, Ali, and Zekeriya Kurşun, eds. Osmanlı Arap coğrafyası ve Avrupa emperyalizmi. İstanbul: Türkiye İş Bankası Kültür Yayınları, 2015.

Al-Maghafi, Fadhl. "More than Just a Boundary Dispute: The Regional Geopolitics of Saudi-Yemeni Relations." SOAS, University of London, 2012. http://eprints.soas.ac.uk/15941/2/Al-Maghafi_3478_vol2.pdf.

Anscombe, Frederick F. The Ottoman Gulf: The Creation of Kuwait, Saudia Arabia, and Qatar. New York: Columbia University Press, 1997.

Ateş, Sabri. Ottoman-Iranian Borderlands: Making a Boundary, 1843-1914. Cambridge University Press, 2013. Bilgin, Pinar. "Thinking Postcolonially about the Middle East: Two Moments of Anti-Eurocentric Critique."

Center for Mellemoststudier, June 2016. https://www.academia.edu/26429001/2016_Thinking _ postcolonially_about_the_Middle_East_Two_moments_of_anti-Eurocentric_critique.

—. "What Is the Point about Sykes-Picot?" Global Affairs 2, no. 3 (May 26, 2016): 355-59. doi: 10.1080/23340460.2016.1236518.

Brunet-Jailly, Emmanuel. "Special Section: Borders, Borderlands and Theory: An Introduction.” Geopolitics 16, no. 1 (January 31, 2011): 1-6. doi: 10.1080/14650045.2010.493765.

Buzpınar, Ş Tufan. “Abdülhamid II and Sayyid Fadl Pasha of Hadramawt.” The Journal of Ottoman Studies 13, no. 13 (1993): 227-39.

Çelebi, Katib. Tuhfet ül-kibâr fi esfâr il-bihâr. Müteferrika, 1729.

Custred, Glynn. "The Linguistic Consequences of Boundaries, Borderlands, and Frontiers." Journal of

Borderlands Studies 26, no. 3 (December 1, 2011): 265-78. doi: 10.1080/08865655.2011.675716.

Danforth, Nick. "Stop Blaming Colonial Borders for the Middle East's Problems." The Atlantic, September 11, 2013. http:/www.theatlantic.com/international/archive/2013/09/stop-blaming-colonial-borders-for-themiddle-easts-problems/279561/.

Devlet-i Aliyye-i Osmaniye 'nin 1313 Senesine Mahsus İstatistik-i Umumiyesidir. İstanbul: Nezaret-i Umur-i Ticaret ve Nafia, 1316.

Elden, Stuart. "Thinking Territory Historically.” Geopolitics 15, no. 4 (November 19, 2010): 757-61. doi: $10.1080 / 14650041003717517$.

- "Why Is the World Divided Territorially?" In Global Politics: A New Introduction, edited by Jenny Edkins and Maja Zehfuss, Second edition., 220-44. Milton Park, Abingdon, Oxon: Routledge, 2014. http://eu.alma. exlibrisgroup.com/view/action/uresolver.do?operation=resolveService\&package_service_id=3039366920002 418\&institutionId=2418\&customerId=2415.

Felton, John. The Contemporary Middle East: A Documentary History. Washington, D.C: CQ Press, 2008.

Filistin Risalesi. Jerusalem: Military Press, 1915.

Garfinkle, Adam. "The Fall of Empires and the Formation of the Modern Middle East." Orbis 60, no. 2 (2016): 204-16. doi: 10.1016/j.orbis.2016.02.001.

Gasparini, Alberto. "Belonging and Identity in the European Border Towns: Self-Centered Borders,

Hetero-Centered Borders.” Journal of Borderlands Studies 29, no. 2 (April 3, 2014): 165-201. doi:

10.1080/08865655.2014.916067.

Gavin, R. J. Aden under British Rule, 1839-1967. Hurst, 1975.

Goettlich, Kerry. “The Rise of Linear Borders in World Politics.” European Journal of International Relations, March 16, 2018. doi: 10.1177/1354066118760991.

Haddad, Mahmoud. "Iraq before World War I: A Case of Anti-European Arab Ottomanism." In The Origins of Arab Nationalism, edited by Rashid Khalidi, Lisa Anderson, Muhammad Muslih, and Reeva S. Simon. New York: Columbia University Press, 1991.

Halliday, Fred. The Middle East in International Relations: Power, Politics and Ideology. Cambridge University 
Press, 2005.

İnalcik, Halil. "Eyalet.” İslam Ansiklopedisi. TDV İslam Araştırmaları Merkezi, 1995. http://www.

islamansiklopedisi.info/dia/pdf/c11/c110350.pdf.

Jäckh, Ernst. Background of the Middle East. Cornell University Press, 1952.

Jones, Stephen B. "Boundary Concepts in the Setting of Place and Time." Annals of the Association of American Geographers 49, no. 3 (1959): 241-55.

Kelidar, Abbas. "States without Foundations: The Political Evolution of State and Society in the Arab East." Journal of Contemporary History 28, no. 2 (1993): 315-339.

Khalidi, Rashid. "The Persistence of the Sykes-Picot Frontiers in the Middle East." London Review of International Law 4, no. 2 (July 2016): 347-57. doi: 10.1093/lril/lrw019.

Kühn, Thomas. "Ordering the Past of Ottoman Yemen, 1872-1914.” Turcica 34 (2002): 189-220.

_. "Shaping and Reshaping Colonial Ottomanism: Contesting Boundaries of Difference and Integration in Ottoman Yemen, 1872-1919." Comparative Studies of South Asia, Africa and the Middle East 27, no. 2 (September 18, 2007): 315-31.

Kurşun, Ali Murat, ed. Osmanlı İran sınırından anılar. İstanbul: Taş Mektep Yayıncılık, 2014.

Kurşun, Zekeriya. Necid ve Ahsa'da Osmanlı hâkimiyeti: Vehhabî hareketi ve Suud Devleti'nin ortaya çıklşı. Ankara: Türk Tarih Kurumu, 1998.

- The Ottomans in Qatar: A History of Anglo-Ottoman Conflicts in the Persian Gulf. The Isis Press, 2002. McMahon, A. H. "The Southern Borderlands of Afghanistan.” The Geographical Journal 9, no. 4 (1897): 393415. doi: $10.2307 / 1774479$.

Minca, Claudio, and Nick Vaughan-Williams. "Carl Schmitt and the Concept of the Border." Geopolitics 17, no. 4 (October 1, 2012): 756-72. doi: 14650045.2012.660578.

Mojtahed-Zadeh, Pirouz. Boundary Politics and International Boundaries of Iran. Universal-Publishers, 2007.

Muhanna, Elias. "Iraq and Syria's Poetic Borders." The New Yorker, August 13, 2014. http://www.newyorker.com/ books/page-turner/iraq-syria-poetic-imagination.

Nazer, Dima W., Maarten A. Siebel, Pieter Van der Zaag, Ziad Mimi, and Huub J. Gijzen. "Water Footprint of the Palestinians in the West Bank." JAWRA Journal of the American Water Resources Association 44, no. 2 (April 2008): 449-58. doi: 10.1111/j.1752-1688.2008.00174.x.

Newman, David. "On Borders and Power: A Theoretical Framework.” Journal of Borderlands Studies 18, no. 1 (March 2003): 13-25. doi: 10.1080/08865655.2003.9695598.

Newman, David, and Anssi Paasi. "Fences and Neighbours in the Postmodern World: Boundary Narratives in Political Geography." Progress in Human Geography 22, no. 2 (1998): 186-207.

Okumuş, Ali. Osmanlı Coğrafyası'nda petrol mücadelesi: Kalust S. Gülbenkyan ve Türk Petrol Şirketi. İstanbul: Taş Mektep Yayıncılık, 2015.

Ortaylı, İlber. Imparatorluḡun en uzun yüzyılı. Timaş Yayınları, 2008.

Ottaway, Marina. "Learning from Sykes-Picot." Middle East Program Occasional Paper Series. Washington, DC: Wilson Center, 2015. https://www.wilsoncenter.org/publication/learning-sykes-picot.

Paasi, Anssi. "Generations and the 'Development' of Border Studies.” Geopolitics 10, no. 4 (December 1, 2005): 663-71. doi: 10.1080/14650040500318563.

Partner, Peter. A Short Political Guide to the Arab World. Literary Licensing, LLC, 1960.

Patel, David Siddhartha. "Repartitioning the Sykes-Picot Middle East? Debunking Three Myths.” Middle East Brief. Crown Center for Middle East Studies, Brandeis University, November 2016. https://www.brandeis. edu/crown/publications/meb/MEB103.pdf.

Prescott, J. R. V. Political Frontiers and Boundaries. 2nd ed. Abingdon: Routledge, 2015.

Rankin, K. J., and Richard N. Schofield. "The Troubled Historiography of Classical Boundary Terminology." In Revised Version of a Paper Presented at the 30th Congress of the International Geographical Union, Glasgow, Scotland, 15-20 August 2004. University College Dublin. Institute for British-Irish Studies, 2004. 
http://researchrepository.ucd.ie/handle/10197/2245.

Rogan, Eugene. "A Century After Sykes-Picot.” Cairo Review, 2015. https://cairoreview-b23.kxcdn.com/wpcontent/uploads/2015/10/CR19-Rogan.pdf.

Ryder, C. H. D. "The Demarcation of the Turco-Persian Boundary in 1913-14.” The Geographical Journal 66, no. 3 (1925): 227-37. doi: 10.2307/1782977.

Sarıkçığlu, Melike. Osmanlı-Iran hudut sorunlarl 1847-1913. Türk Tarih Kurumu, 2013.

Stansfield, Gareth. "The Remaking of Syria, Iraq and the Wider Middle East.” RUSI, July, 2013. https://rusi.org/ sites/default/files/201307_bp_the_remaking_of_syria_iraq_and_the_wider_middle_east_final.pdf.

Sykes, Mark, and F. Georges-Picot. "Map of Eastern Turkey in Asia, Syria and Western Persia". UNISPAL, 1916. http://unispal.un.org/unispal.nsf/3d14c9e5cdaa296d85256cbf005aa3eb/232358bacbeb7b55852571100078477 c?OpenDocument, retrieved 19/08/2014. abbr.: United Nations, 1916.

Traboulsi, Fawwaz. A History of Modern Lebanon. 2 edition. London : New York: Pluto Press, 2012.

Winichakul, Thongchai. Siam Mapped: A History of the Geo-Body of a Nation. University of Hawaii Press, 1994. Yerasimos, Stefanos. Milliyetler ve sinırlar: Balkanlar, Kafkasya ve Ortadoğu. İstanbul: İletişim Yayınları, 1994. 